\title{
Students can stay in US
}

\section{Washington}

THE US Senate passed a bill last week that would permit the 40,000 people from the People's Republic of China studying in the United States to remain in the country until such time as the administration rules that it is safe for them to return home. A similar bill in the House of Representatives could be put to a vote within weeks. But it is not yet certain that the measure will become law; some critics feel the action is too hasty and too drastic.

Bill Carroll of the National Association of Foreign Student Affairs (NAFSA), which has 6,500 colleges and universities as its members, says the measures could "jeopardize the future of international educational exchanges" by discouraging the government of China from sending students abroad. NAFSA is in favour of simply extending the length of time students may stay. The new bill would provide an automatic one-year extension of all visas held by Chinese students and then allow changes in residency status, possibly leading to permanent residence.

Chinese students who wish to come to the United States are still applying for visas at the US embassy and Chinese academics due to come here on study trips are also continuing to arrive. But despite the appearance of normality, arrests are still being reported daily in China for "actively supporting the spread of bourgeois liberalization". More than 2,500 arrests have been made.
Further arrests reported by the human rights group Asia Watch include 15 students, researchers and faculty; most were at institutions based in Beijing. Among them are Cheng Mingyuang, a professor at the Foreign Languages Institute in Beijing who had also been imprisoned during the Cultural Revolution while working for the Chinese Academy of Sciences; and Zhao Yiqiang, a teacher at Beijing Medical University and his wife. Trials and sentences publicly reported so far have been of workers, not students.

Although Chinese student organizations have been calling for harsh sanctions against China, and a bill passed by the Senate last Friday called on the president to review the whole range of ecomonic ties between the United States and China, Chinese academics warn against too harsh a response. No US academic body has followed the example of the National Academy of Sciences and 'suspended' exchanges with China. Chinese academics in the United States say such moves may harm the very people they wish to help.

Universities will also be looking out for the safe return of Chinese students who went home during the summer vacation and should be back in the United States in Septemeber to resume their studies. At least one academic will not be returning. Liu Xiabao, a visiting scholar at Columbia University and a known dissident, was arrested in June after returning to Beijing.

Christine McGourty \& Alun Anderson

\section{Cetus banks on interleukin}

\section{San Francisco}

A MAJOR gamble by the embattled genetic engineering firm company Cetus finally bore fruit last week, as Denmark became the first nation to approve the California company's immunostimulatory drug interleukin-2(IL-2).

In May, the European Community (EC)'s Committee for Proprietary Medicinal Products recommended the drug's approval, raising Cetus's hopes that other EC nations will quickly follow the Danish example. Cetus has paid out $\$ 100$ million over eight years to develop IL-2 as its flagship drug, banking on a vast market worth several times its investment stake. The drug, which Cetus will market as Proleukin, has been approved only for renal cancer. But human trials indicate that its benefits may extend to many other conditions, including melanoma, ovarian cancer, leprosy, hepatitis and AIDSassociated Kaposi's sarcoma.

On top of years of research investment, Cetus endured a bitter patent battle with competitor Hoffmann-La Roche Inc. before the two companies reached a crosslicensing agreement last December Even though this means sharing royalties, Cetus president Robert Fildes predicts that Proleukin will generate several hundred million dollars in sales. US approval of the drug is expected by mid-1990.

For a company with a stock price which has long been depressed and with only $\$ 30$ million of sales in the 1988 fiscal year, the Danish decision is welcome news. But more problems lie ahead.

Cetus has retained all marketing rights to Proleukin, breaking a tried-and-true industry tradition of licensing products to more established partners for marketing. The company will sell the drug through distributors or its wholly owned subsidiary, Amsterdam-based EuroCetus, putting an enormous strain on operating margins.

Fildes maintains that the decision is sound. He says the incremental cost to Cetus of going into Europe on its own is probably 25 per cent, which makes a lot more sense than settling for a 5 or 10 per cent royalty.

Robert Buder
No new money from US government?

\section{Washington}

A PANEL of scientists asked by the US Department of Energy (DoE) to look into claims of cold fusion has concluded that the experiments have not presented "convincing evidence" for excess heat production and that no special programmes or new efforts in cold fusion research are justified. The panel, chaired by J. R. Huizenga of the University of Rochester and N. F. Ramsey of Harvard University, was convened by the DoE's Energy Research Advisory Board (ERAB). Its report has yet to be officially approved by ERAB, but no significant changes are expected before it is sent to DoE Secretary James Watkins.

Although members of the panel visited laboratories at the University of Utah and at Stanford and Texas A\&M Universities, where electrolysis experiments producing excess heat have been reported, they saw no working cells, and concluded that in none of the claims was the precision of the calorimetric measurements sufficient to "persuasively demonstrate" the production of excess heat. The lack of fusion products in quantities consistent with the claimed power output also detracts significantly from the credibility of the claims.

The report does say that the low-level version of cold fusion, as indicated by the small neutron fluxes measured first by Steven Jones and his colleagues at Brigham Young University, may be of scientific interest, and that in some experiments are purported to generate excess heat there are sporadic temperature 'spikes' that merit further study. But neither of these phenomena holds promise for useful largescale energy production.

David Lindley NUCLEAR ENERGY

\section{Food processors from Wackersdorf}

\section{Munich}

THE Bavarian government on 4 July signed an agreement to allow the company Wilden KG to produce kitchen appliances on the site of the abandoned nuclear reprocessing plant at Wackersdorf beginning next spring. It will complement the solar energy cell factory that Siemens AG and the electric utility Bayernwerke plan to erect on the site. The West German government had invested about DM2,600 million $\mathbf{( \$ 1 , 3 7 0}$ million) in the site before the project was abandoned this spring (see Nature 339, 413; 8 June 1989).

The 4,800-metre long, 3-metre high security fence, which was the site of dozens of demonstrations against the plant, will probably remain, said spokesman WolfDieter Remmele of the Bavarian government. After all, he said, "Even private companies need security".

Steven Dickman 